\author{
N.I. Kopylov \\ Institute of Solid State Chemistry and Mechanochemistry \\ of the Siberian Branch of the Russian Academy of Sciences, Novosibirsk, Russia \\ (E-mail:kolyubov@narod.ru)
}

\title{
Thermolysis of brown coal from the Baganursky deposit (Mongolia)
}

\begin{abstract}
The process of thermolysis of brown coal from the Baganursky deposit of Mongolia has been studied. These coals are characterized by high content of gas component (up to $40 \%$ ) and low content of liquid fraction. The decomposition begins at $\sim 200{ }^{\circ} \mathrm{C}$. At temperatures up to $\sim 700{ }^{\circ} \mathrm{C}$ there is no sintering. In the solid residue, only relicts of the individual hydrocarbon constituents of the original coal are retained. The liquid condensate of sublimates (up to $19 \%$ by weight of the initial) contains $0.78 \%$ of the organic extract (96-98\% of the phenolic mass with a maximum boiling point of $360{ }^{\circ} \mathrm{C}$ ) and $92.2 \%$ of the aqueous solution (with a boiling range of $115-130^{\circ} \mathrm{C}$ ). The initial aggregate state (the particle size of the material, the effect on it of the external medium) not only affects the yield of the gas constituent of coal during thermolysis, but also determines the impurity composition of the organic extract of the condensate liquid sublimates.
\end{abstract}

Keywords: thermolysis, brown coals, solid residue, sublimates, condensate, hydrocarbons, phenols, thermal analysis.

\section{Introduction}

Fossil coals are subdivided into anthracites, stone and brown coals. Depending on the composition, physical and technological properties, as well as economic, social and other factors, the coals of particular deposits can be used as energy or technological raw materials. Currently, they mainly serve as a fuel resource. At the end of the last century, up to $73 \%$ of the extracted fossil coals were used for this purpose in the USSR [1].

When burning in the furnaces of boiler houses and domestic ovens, a large amount of volatile components is released and incomplete coal burnout spores are formed, which leads to a systemic release of environmentally hazardous combustion products into the atmosphere. In the conditions of the mountainous terrain and the continental climate in Central Asia, for example, on the territory of the Republic of Tuva, stagnant zones, smog in the surface space of the «wind shadow effect» and pollution of the atmosphere of cities and settlements of the region with harmful products of flue gases: carcinogens and other highly toxic substances [2].

Similarly, an analogical adverse environmental situation is observed in the adjacent coal-mining regions of Mongolia. For example, at the Khushut coal deposit of lean coal, production is conducted only for the energy needs of the local population [3]. Also, mainly for domestic needs and thermal power engineering, deposits of a number of brown and hard coals of Mongolia are being developed [4]. At the same time, environmental problems of flue emissions have not been solved, both for large stationary TS and TPPs, and for private sector furnaces of cities and settlements of regions that use coal to be extracted as a source of thermal energy.

In this regard, within the framework of the comprehensive Program for the Creation of Technologies for the Efficient and Environmentally Safe Processing of Mineral Raw Materials (SB RAS project No. 28.4.8, 2004-2006) in TuVIKOPR SB RAS, (Kyzyl) in cooperation with ISTTM SB RAS (Moscow). Novosibirsk), investigations were carried out on the dynamics of thermolysis of coals of Tuva with the aim of working out a process for obtaining environmentally friendly fuel material [5]. Interest in this topic from Mongolian specialists served as a basis for research on the thermal decomposition of coals of Mongolian deposits. Within the framework of the program of these investigations, work was carried out to investigate the thermolysis of coals of individual deposits in Mongolia [6, etc.].

This report is devoted to the results of investigations of the thermal decomposition of brown coals of the Baganursky deposit.

\section{Experimental part}

The technical characteristics of the samples of this coal are given in Table 1. 
Table 1

Technical characteristics of the samples of coal

\begin{tabular}{|c|c|c|c|c|c|c|c|c|}
\hline \multirow{2}{*}{$\begin{array}{l}\text { Sample of Baganur } \\
\text { stone coal }\end{array}$} & \multicolumn{3}{|c|}{ Technical analysis, $\%$} & \multicolumn{4}{|c|}{ Elemental composition on dax } & \multirow{2}{*}{ Calorie $\mathrm{Q}^{\mathrm{s}}, \mathrm{kg} / \mathrm{cal}$} \\
\hline & $\mathrm{W}^{\mathrm{s}}$ & $A^{d}$ & $\mathrm{~V}^{\mathrm{dax}}$ & $\mathrm{C}$ & $\mathrm{H}$ & $\mathrm{S}$ & $\mathrm{O}+\mathrm{S}+\mathrm{N}$ & \\
\hline Sample 1 & 8.4 & 10.4 & 41.1 & 72.0 & 4.9 & 0.36 & 22.9 & 5034.4 \\
\hline Sample 2 & 9.3 & 10.2 & 42.5 & 70.0 & 4.1 & 0.49 & 21.5 & 4991.0 \\
\hline
\end{tabular}

The material for the investigation was initially presented in the form of a single sample, and then in addition - an aggregate batch weighing about $3 \mathrm{~kg}$, which was a mixture of lumps of various sizes mixed with a small rash. At the first stage, the dynamics of thermal decomposition were investigated by differential thermal analysis (DTGA) using the MOM-1000 derivatograph (type «Paulik, Paulik-Erdei», Hungary). The weight of the sample was $\sim 1 \mathrm{~g}$. The starting material was previously divided into three fractions: freeflowing, medium-sized $(5-20 \mathrm{~mm})$ and lump $(>20 \mathrm{~mm})$. Heating was carried out to $650-700{ }^{\circ} \mathrm{C}$ at a rate of $10^{\circ} \mathrm{C} / \mathrm{min}$. The experimental conditions provided for the free diffusion of gaseous constituents of coal formed in the sample upon heating, but excluding contact with the air medium.

Determination of the quantitative characteristics of the process was carried out in a laboratory facility with the capture of gas and light boiling condensates, including a container placed in the furnace, into which a crucible with a sample was connected, connected by a branch pipe with a system for capturing sublimations. The mass of samples in these experiments was in the range of 50-100 g.

Investigations of thermolysis products were carried out by a number of methods of instrumental analysis: DTGA, IR spectroscopy, chromatography-mass spectroscopy.

DTGA single sample. Figure 1 and Table 2 show the data of the DTGA of samples of material of various sizes.

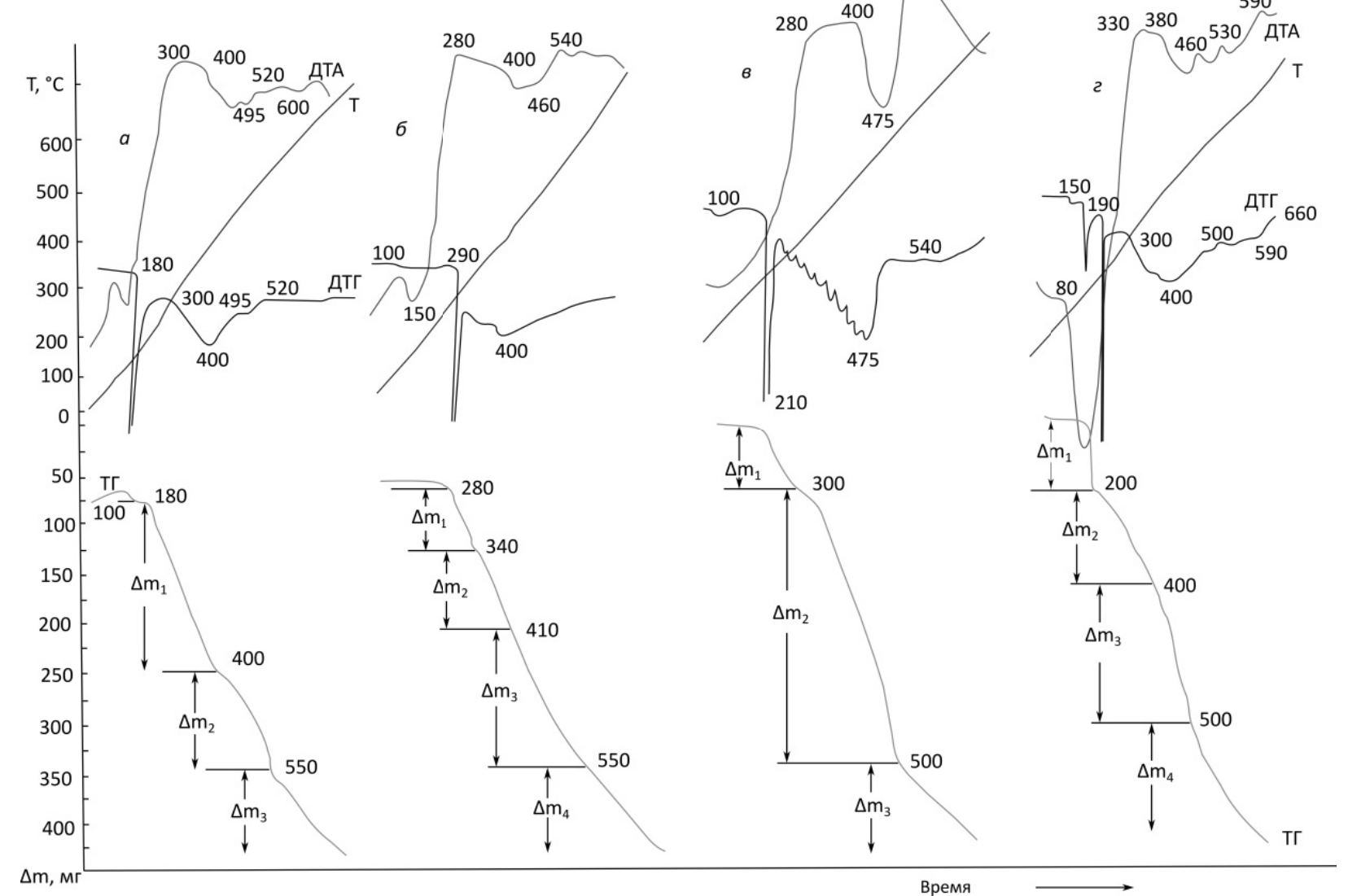

Figure 1. DTGA of a single (initial) coal sample: $a$ - $g$ (see Table 2) 
Table 2

Thermal decomposition of brown coal from the Baganursky deposit

\begin{tabular}{|c|c|c|c|c|c|c|c|c|}
\hline \multirow{3}{*}{$\begin{array}{l}\text { Steps } \\
\text { of decom- } \\
\text { position }\end{array}$} & \multicolumn{8}{|c|}{ Initial sample*) } \\
\hline & \multicolumn{2}{|c|}{$a$} & \multicolumn{2}{|c|}{$b$} & \multicolumn{2}{|c|}{$c$} & \multicolumn{2}{|c|}{$d$} \\
\hline & Interval, $\mathrm{t}^{\circ} \mathrm{C}$ & $\begin{array}{c}\text { Weight loss } \\
\text { from the } \\
\text { initial, } \%\end{array}$ & Interval, $\mathrm{t}^{\circ} \mathrm{C}$ & $\begin{array}{l}\text { Weight loss } \\
\text { from the } \\
\text { initial, } \%\end{array}$ & Interval, $\mathrm{t}^{\circ} \mathrm{C}$ & $\begin{array}{l}\text { Weight loss } \\
\text { from the } \\
\text { initial, } \%\end{array}$ & Interval, $\mathrm{t}^{\circ} \mathrm{C}$ & $\begin{array}{l}\text { Weight loss } \\
\text { from the } \\
\text { initial, } \%\end{array}$ \\
\hline 1 & $80-100$ & 0.2 & $100-150$ & 0.5 & 100 & - & $80-150$ & \multirow{2}{*}{5.5} \\
\hline 2 & $180-300$ & \multirow{2}{*}{17.1} & $280-300$ & 6.5 & $210-300$ & 7.0 & $150-200$ & \\
\hline 3 & $300-400$ & & $300-400$ & 10.5 & $300-400$ & 27.5 & $200-400$ & 11.2 \\
\hline 4 & $400-550$ & 10 & $410-500$ & \multirow{2}{*}{21.5} & $400-500$ & & $400-500$ & 12.4 \\
\hline 5 & $550-700$ & 12 & $500-700$ & & $500-700$ & 8.0 & $500-650$ & 7.0 \\
\hline$\Sigma$ & 700 & $\sim 39 \%$ & 700 & $\sim 40 \%$ & 700 & $\sim 42.5$ & 650 & $\sim 36.1$ \\
\hline
\end{tabular}

Note. *) $a$ - lump sample, fresh prepared; $b$ - lump, previously prepared; $c$ - fresh prepared rash sample; $d$ - rash sample, previously prepared.

It can be seen that with the general identity of the results of individual samples on the curves, there are differences in the course of their sections characterizing the individual stages of thermolysis. On the DTA curves for samples in experiments with samples $a, b, d$ (see Fig. 1), a clear cascade of endoeffects is fixed in the interval $380-600^{\circ} \mathrm{C}$, corresponding to the phased removal of gaseous and low-boiling decomposition products from the material. However, in the case of a sample in (Fig. 1), instead of a cascade of thermal effects, only one large endopic is observed in the range of $\sim 400-540^{\circ} \mathrm{C}$. Such a variety of curves on thermograms at the initial stage of heating can be explained by the initial state of the material: the size, the conditions of its content from the time of extraction to sampling (contact with the air medium and storage time). Nevertheless, the decomposition sequence is the same for all samples (Table 2): the process begins with explosive gas evolution at relatively low temperatures in the amount of 5.5-7.0\% of the initial one. For trials a and $\mathrm{c}$, the association is combined into a single stage with the subsequent or with the previous stage. The total weight loss varies between $36.1-42.5 \%$, depending on the final temperature of the experiment.

DTGA samples of the coarse lot. The results of the experiments (Fig. 2) basically agree with the data of the experiments of a single sample (Fig. 1). Thus, the loss of the mass of the samples upon heating (TG and DTG curves) is carried out step-by-step at $80-200$ and $300-470{ }^{\circ} \mathrm{C}$ : by 9.4 and $14.7 \%$, respectively (for small intermediate loss $\Delta \mathrm{m}^{2}=2.7 \%$ ). With further heating, the monotonic mass loss $\left(\Delta \mathrm{m}^{4}\right)$ is $14.1 \%$. The total mass loss of the sample reaches $\sim 41 \%$, and in some experiments $-47 \%$.

Consistency of the decomposition products of coal. Determination of the consistency of the decomposition products was carried out in the following modes: 1) continuous heating to $600-650{ }^{\circ} \mathrm{C}$ with an exposure of 1-2 hours at a finite temperature; 2) stage-by-stage heating (with a 2-hour exposure through $100^{\circ} \mathrm{C}$ ) to $600-650^{\circ} \mathrm{C}$ (see Table 3$)$.

Ta b le 3

The results of thermolysis of brown coal with a gradual aging

\begin{tabular}{|c|c|c|c|c|c|c|}
\hline \multirow{2}{*}{$t,{ }^{\circ} \mathrm{C}$} & \multicolumn{3}{|c|}{ Experiment 1, monolith sample } & \multicolumn{3}{c|}{ Experiment 2, intermediate sample } \\
\cline { 2 - 7 } & $\Delta \mathrm{P}, \%$ & Condensate, $\%$ & Gas fraction, $\%$ & $\Delta \mathrm{P}, \%$ & Condensate, $\%$ & Gas fraction, $\%$ \\
\hline 200 & 18.73 & 0.28 & 18.44 & 9.5 & 6 & 3.5 \\
\hline 300 & 9.3 & 1.5 & 7.54 & 10.04 & 4.04 & 6 \\
\hline 400 & 10.2 & 3.65 & 6.6 & 9.74 & 4.14 & 5.6 \\
\hline 500 & 6.58 & 0.64 & 5.94 & 7.7 & 2 & 5.7 \\
\hline 600 & 5.03 & 0.37 & 4.66 & - & - & - \\
\hline 650 & - & - & - & 5.05 & 1.9 & 3.15 \\
\hline$\sum$ & 49.94 & 6.39 & 43.55 & 42.03 & 18.08 & 23.95 \\
\hline
\end{tabular}

The results of the experiments of regimes 1 and 2 differ somewhat, but on the whole they correlate according to the main parameters. Thus, in the case when the initial sample was an initial coal monolith (experiment No. 1, Table 3), a significant loss of mass (18.73\%) was observed already at $200^{\circ} \mathrm{C}$, mainly as a gas 
component. At the same time, in an experiment with an average breakdown of fines (experiment No. 2, Table 3) at a holding temperature of $200{ }^{\circ} \mathrm{C}$, the mass loss is only $9.5 \%$. Extracts at subsequent temperature stages in both experiments lead to comparable mass losses, differing only in the gaseous components. The final results differ only due to the mass loss at $200^{\circ} \mathrm{C}$.

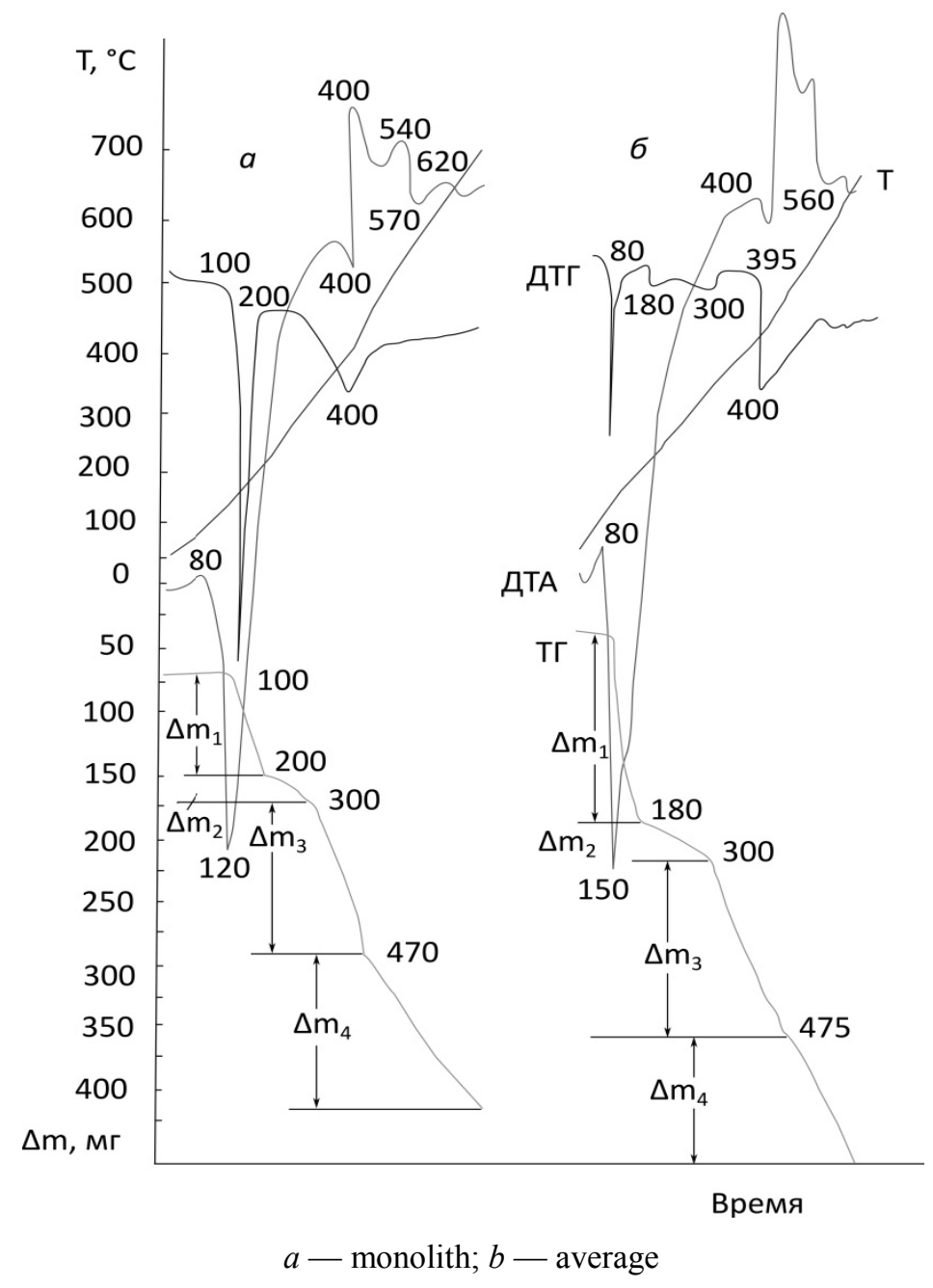

Figure 2. DTGA of the coarse coal lot

The total loss of mass of experiment No. 1 is $49.94 \%$ and is determined primarily by the gas component (43.55\%), and the total loss in experiment No. 2 is $42.03 \%$ and is determined by equally condensed sublimates $(18.08 \%)$ and gas constituents $(23,95 \%)$, while the number of the latter is almost half that of experiment No. 1. This difference is due to the partial loss of gaseous components in the case of sample No. 2 due to diffusion weathering during storage under conditions of free contact with the environment.

In the investigation, along with the study of the dynamics of the thermal decomposition of coal, quantitative characteristics of the decomposition process were determined and a solid residue and liquid condensates of the sublimes of the low-boiling constituents of coal were obtained.

For a comparative evaluation of the thermolysis result, an $\mathrm{X}$ analysis of the average initial lot of coal and its solid thermolysis product was carried out.

The IR spectrum of the initial coal sample (Fig. 3, curve 1) includes absorption bands corresponding to out-of-plane vibrations of aromatic $\mathrm{CH}$ bonds in the range $1000-1100 \mathrm{~cm}^{-1}$; ether in the region of 1150 $1350 \mathrm{~cm}^{-1}$; $\mathrm{C}-\mathrm{O}$ phenolic in the region $1550-1650 \mathrm{~cm}^{-1} ; \mathrm{C}=\mathrm{O}$ quinolones in the region of $2845-2020 \mathrm{~cm}^{-1}$; $\mathrm{CH}$-aliphatic and $\mathrm{OH}$ groups of phenols and carboxylic acids in the region of $3100-3400 \mathrm{~cm}^{-1}$ and their peripheral groups in the $3500-3600 \mathrm{~cm}^{-1}$ region. The IR spectra of the material after thermolysis (Fig. 3, curve 2), as a rule, have relict absorption bands corresponding to weakly pronounced vibrations, and in regions of $2500 \mathrm{~cm}^{-1}$ there are no vibrational bands. 


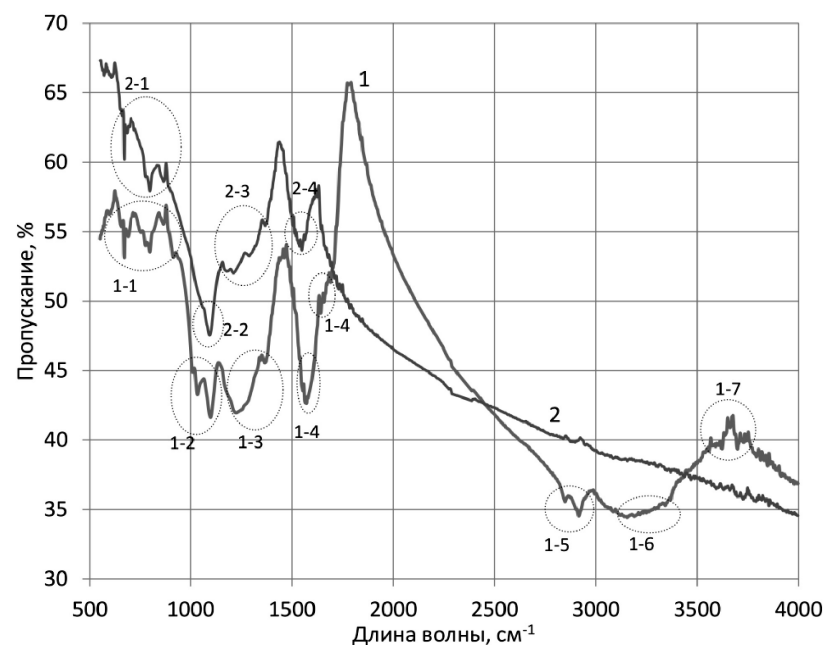

Figure 3. IR spectrograms of the average initial sample of brown coal (1) and the product of its thermolysis (2)

The results of DTGA liquid condensate sublimation of coal thermolysis (samples I, II and average enlarged lot) obtained after holding at 600,300 and $400{ }^{\circ} \mathrm{C}$ (Fig. 4) showed that in the temperature range 115$130{ }^{\circ} \mathrm{C}$ all the sample material passes into vapor. In this case, the complete identity of the thermograms of all samples is noted.

The liquid condensate of the thermolysis of the average sample of the coarse lot of coal was extracted with chloroform, extracting an extract in an amount of $0.78 \%$ of the mass of the liquid condensate. The main part of the liquid condensate of sublimates is an aqueous solution. IR spectra of the extract of the middle sample contain the following characteristic absorption bands: 1 - saturated fragments of molecules (maxima 1377, 1463, 2728, $\left.2854 \mathrm{~cm}^{-1}\right) ; 2$ - aromatic structures $\left(722,744,812,874,1604 \mathrm{~cm}^{-1}\right) ; 3$ - oxygencontaining compounds $\left(1032,1167,1706 \mathrm{~cm}^{-1}\right)$. This thermolysis product contains phenol, two isomers of methylphenols and two isomers of ethylphenols, as well as n-alkanes and $\alpha$-olefins (in minimal amounts).
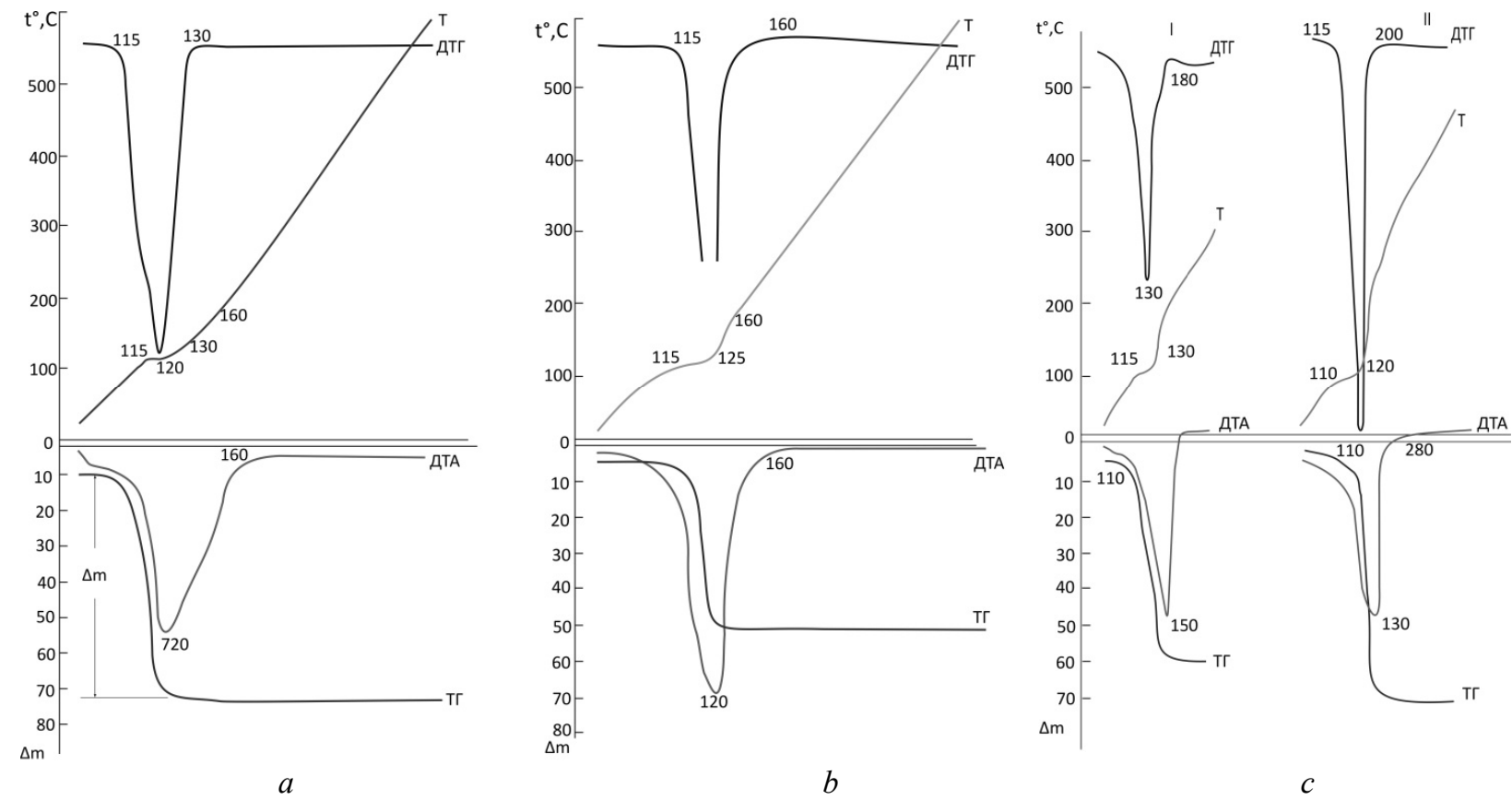

Figure 4. DTGA of the liquid extract of the sublimations of thermolysis of samples I $(a)$ and II $(b)$ in the temperature range up to $600{ }^{\circ} \mathrm{C}$, and also of the average coal sample (c) in the temperature range up to 300 (I) and $400{ }^{\circ} \mathrm{C}$ (II)

The results of chromatographic determination of the consistency of organic products of the extract of the sublimations of thermolysis of samples I and II are given in Table. 4. The bulk of the extracted organic component is also represented by phenol and its derivatives. 
$\mathrm{Tab}$ a 4

Material composition of the extract of the condensate of the sublimes of thermolysis of the Baganurian coal

\begin{tabular}{|c|c|c|c|}
\hline Peak No. & Substance & $\begin{array}{l}\text { Retention time, } \\
\text { minutes }\end{array}$ & $\begin{array}{c}\text { Relative } \\
\text { content, \% }\end{array}$ \\
\hline \multicolumn{4}{|c|}{ Sample I } \\
\hline 1 & Phenol & 4.6 & 36.45 \\
\hline 2 & 2-Methylphenol & 5.3 & 14.45 \\
\hline 3 & 3-Methylphenol & 5.5 & 32.57 \\
\hline 4 & 2,6-Dimethylphenol & 5.9 & 0.45 \\
\hline 5 & 2-Ethylphenol & 6.1 & 0.90 \\
\hline 6 & 2,4-Dimethylphenol & 6.3 & 5.03 \\
\hline 7 & 3-Ethylphenol & 6.4 & 7.27 \\
\hline 8 & 2,3-Dimethylphenol & 6.6 & 0.74 \\
\hline 9 & 3,4-Dimethylphenol & 6.7 & 1.44 \\
\hline 10 & 3-Propylphenol & 7.4 & 0.69 \\
\hline \multicolumn{4}{|c|}{ Sample II } \\
\hline 1 & 3-Methylpyridine & 5.0 & 0.2 \\
\hline 2 & 2,6-Dimethylpyridine & 5.8 & 0.08 \\
\hline 3 & 2-Methyl-2-cyclopentene-1-one & 6.1 & 0.3 \\
\hline 4 & 3-Methyl-2-cyclopentene-1-one & 7.0 & 1.12 \\
\hline 5 & Phenol & 7.3 & 60.26 \\
\hline 6 & 2,3-Dimethyl-2-cyclopentene-1-one & 8.2 & 0.71 \\
\hline 7 & 2-Methylphenol & 8.5 & 6.21 \\
\hline 8 & 4-Methylphenol & 9.0 & 27.25 \\
\hline 9 & 2,5-Dimethylphenol & 10.2 & 1.06 \\
\hline 10 & 3-Ethylphenol & 10.8 & 2.69 \\
\hline
\end{tabular}

In the extract of condensate, there are also small amounts of cyclopentene and pyridine derivatives, there is an insignificant amount of the phase relating to alkanes and olefins.

Within a general identity of the phase composition of the extracts of the average sample of the aggregated lot, samples I and II (96-99 \% phenol and its derivatives), the proportions of the constituent phases are slightly different. Also, in the extract of sample II there is an admixture of the cyclopentene derivative, and in the extract of the intermediate sample condensate, an admixture of naphthalene derivatives. This is probably due to the different initial aggregate state of the materials of these samples: the particle size, which determines the contact surface with the external medium of the starting material, and the degree of reaction of this factor to it.

Based on the investigation data, it is possible to imagine the thermal decomposition of the Baganur brown coal by the following scheme:

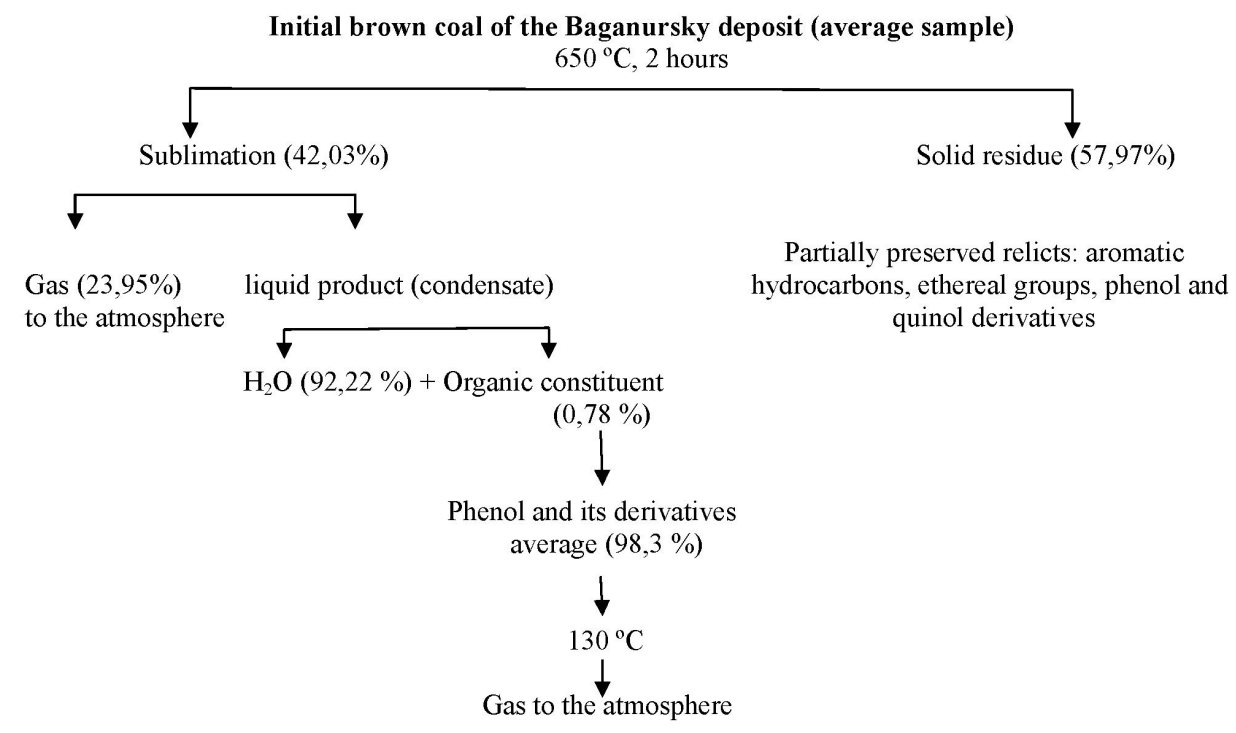




\title{
Conclusion
}

The conducted study of the thermolysis of brown coal from the Baganursky deposit showed that it is characterized by a high content ( $>40 \%$ ) of gaseous components, which are removed from the material when heated in the range of $\sim 200^{\circ} \mathrm{C}$, minor admixtures of liquid condensate and absence of astringent constituents. The material does not cake. The solid-phase residual thermolysis product is a free-flowing graphite-like material, which can be briquetted only by the introduction of astringent formulations. Liquid condensate consists of $99.22 \%$ of the aqueous solution and $0.78 \%$ of the organic component - phenol and its derivatives. The condensate boils away without residue in the range $115-130^{\circ} \mathrm{C}$. Investigation on samples of a material with various sizes: medium sample of a coarse batch, fine (sample I - size $<5 \mathrm{~mm}$ ) and large (sample II - diagonal size $>30 \mathrm{~mm}$ ) fractions showed that the initial aggregate state of the material, the degree of environmental impact on it influence not only the yield of the gas component during thermolysis, but also the phase composition of the extract of the condensate of sublimation.

\section{References}

1 Горная энциклопедия. - Т. 5. - М.: Сов. энцикл., 1991. - С. 227.

2 Шабанов В.И. Марочный состав углей пласта Улуг Улуг-Хемского бассейна / В.И. Шабанов, И.Ю. Яковлев // Химия твердого топлива. - 1989. - № 6. - С. 52-55.

3 Bat-Orahikh Erdenetsogt, Insung Lee, Belegiin Bat-Erdene, Luvsanhultem Jargal // Int. J. Coal Geol. — 2009. — Vol. 80. — P. 87.

4 Геология Монгольской народной республики / Под ред. Н.А. Миронова, Р.А. Хасина, Ч. Хурц. — М.: Недра, 1977, $125 \mathrm{c}$.

5 Копылов Н.И. Термическое разложение углей Тувинского месторождения / Н.И. Копылов, Ю.Д. Каминский // Химия в интересах устойчивого развития. - 2013. - Т. 21, № 3. - С. 319-327.

6 Копылов Н.И. Термолиз бурого угля Баганурского месторождения (Монголия) / Н.И. Копылов, Ю.Д. Каминский, Ж. Дугаржав, Б. Авид, Ю.В. Патрушев // Химия в интересах устойчивого развития. — 2013. — Т. 21, № 5. — С. $499-504$.

\section{Н.И. Копылов}

\section{Баганур кен орнының (Монғолия) қоңыр көмірінің термолизі}

\begin{abstract}
Баганур кен орнының (Монғолия) қоңыр көмірінің термолизі үрдісі зерттелді. Бұл көмірлер газдардың көп мөлшерімен (40\% дейін) және сұйық фракцияның $\sim 200^{\circ} \mathrm{C}$ басталады. $\sim 700{ }^{\circ} \mathrm{C}$ дейінгі температурада пісу болмайды. Қатты қалдықта бастапқы көмірдің тек жеке көмірсутекті құрамдастарының реликтері кездеседі. Айдаудың сұйық конденсатында (бастапқы мөлшерден 19 \% дейін) $0,78 \%$ органикалық экстракт (96-98\% фенолды масса, максималды қайнау температурасы $360{ }^{\circ} \mathrm{C}$ ) және 92,2\% сулы ерітінді (қайнаудың температуралық интервалы $115-130{ }^{\circ} \mathrm{C}$ ) болады. Бастапқы агрегаттық күй (материал бөлшектерінің ірілігі, оған қоршаған ортаның әсері) термолиз кезінде көмірдің газдық құрамдасының шығымына әсер етіп ғана қоймай, айдаудың сұйық конденсатының қоспалық құрамына да ықпал етеді.
\end{abstract}

Кілт сөздер: термолиз, қоңыр көмірлер, қатты қалдық, айдау, конденсат, көмірсутектер, фенолдар, термиялық талдау.

\section{Н.И. Копылов}

\section{Термолиз бурого угля Баганурского месторождения (Монголия)}

Изучен процесс термолиза бурого угля Баганурского месторождения Монголии. Данные угли отличаются высоким содержанием газовой составляющей (до 40 \%) и низким содержанием жидкой фракции. Разложение материала начинается при $\sim 200{ }^{\circ} \mathrm{C}$. При температурах вплоть до $\sim 700{ }^{\circ} \mathrm{C}$ спекание отсутствует. В твёрдом остатке сохраняются только реликты отдельных углеводородных составляющих исходного угля. Жидкий конденсат возгонов (до $19 \%$ мас. от исходного) содержит 0,78 \% органического экстракта (96-98 \% фенольной массы с максимальной температурой выкипания $\left.360{ }^{\circ} \mathrm{C}\right)$ и $92,2 \%$ водного раствора (с температурным интервалом кипения $115-130{ }^{\circ} \mathrm{C}$ ). Исходное агрегатное состояние (крупность частиц материала, воздействие на него внешней среды) не только влияет на выход газовой составляющей угля при термолизе, но и определяет примесный состав органического экстракта жидкого конденсата возгонов. 
Ключевые слова: термолиз, бурые угли, твёрдый остаток, возгоны, конденсат, углеводороды, фенолы, термический анализ.

\section{References}

1 Gornaia entsyclopediia [Mountain encyclopedia]. (1991). (Vol. 5). Moscow: Sovetskaia entsiklopediia [in Russian].

2 Shabanov, V.I., \& Yakovlev, I.Yu. (1989). Marochnyi sostav uhley plasta Uluh Uluh-Khemskoho basseina [Vintage composition of coals of the Ulugh Ulug-Khem basin]. Khimiia tverdoho topliva - Solid Fuel Chemistry, 6, 52-55 [in Russian].

3 Bat-Orahikh Erdenetsogt, Insung Lee, Belegiin Bat-Erdene, \& Luvsanhultem Jargal (2009). Int. J. Coal Geol., 80, 87.

4 Mironova, N.A., Khasina, R.A., \& Khurts, Ch. (Eds.). (1977). Heolohiia Monholskoi Narodnoi Respubliki [Geology of the Mongolian People's Republic]. Moscow: Nedra [in Russian].

5 Kopylov, N.I., \& Kaminskii, Yu.D. (2013) Termicheskoe razlozhenie uhlei Tuvinskoho mestorozhdeniia 「Thermal decomposition of coals of the Tuva deposit]. Khimiia v interesakh ustoychivoho razvitiia - Chemistry for Sustainable Development, 21, 3, 319-327 [in Russian].

6 Kopylov, N.I., Kaminskiy, Yu.D., Dugarzhav, Zh., Avid, B., \& Patrushev, Yu.V. (2013). Termoliz buroho uhlia Bahanurskoho mestorozhdeniia (Monholiia) [Thermolysis of brown coal from Boganursky deposit (Mongolia)]. Khimiia v interesakh ustoichivoho razvitiia - Chemistry for Sustainable Development, 21, 5, 499-504 [in Russian]. 